\title{
The Impact of Corporate Governance on Financial Performance of Companies in Southern Africa
}

\author{
Abubakar Balarabe KARAYE iD a Göknur BÜYÜKKARA iD a \\ a Hacettepe University, Department of Business Administration, Ankara, Turkey. abkaraye501@yahoo.com \\ b Hacettepe University, Department of Business Administration, Ankara, Turkey. goknur@hacettepe.edu.tr
}

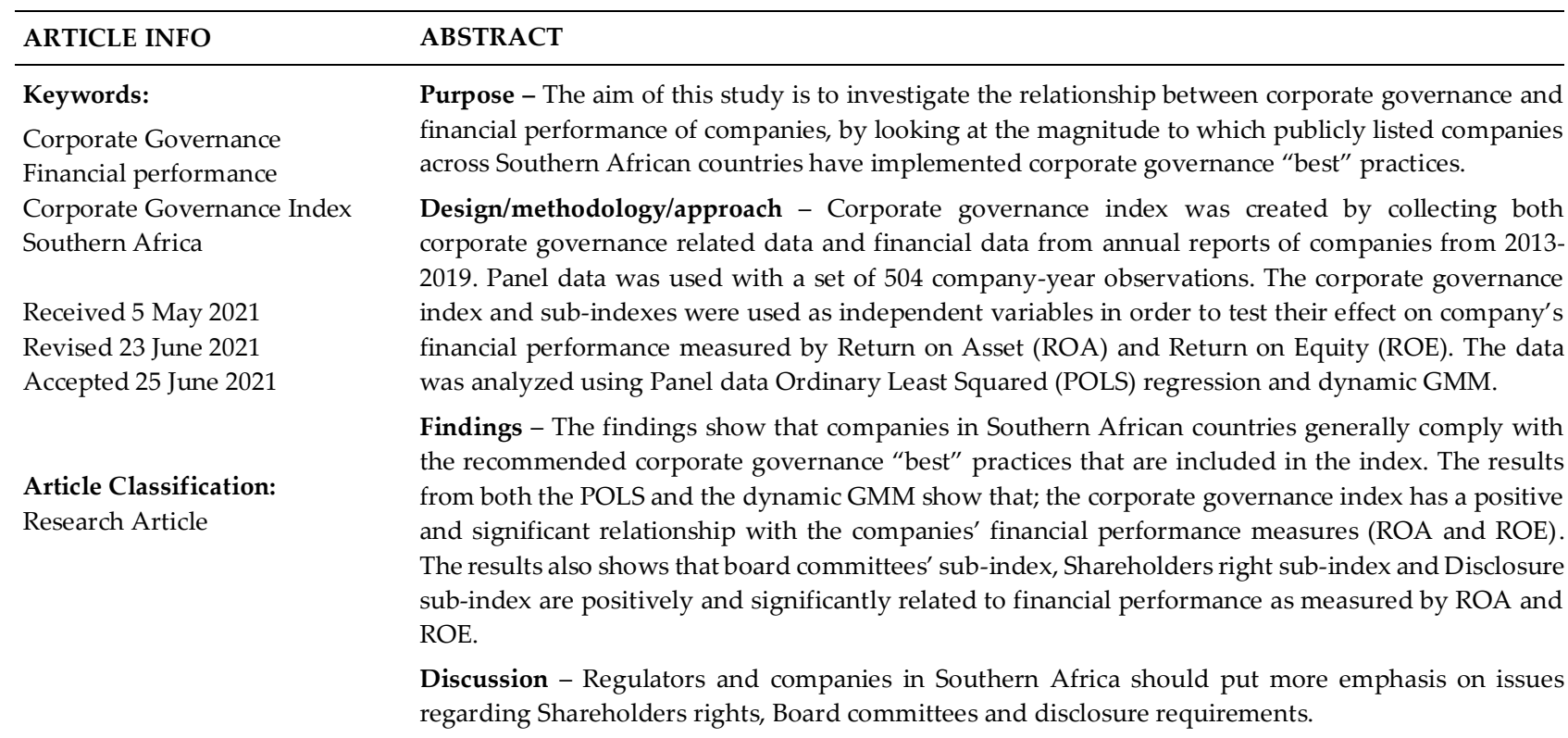

\section{Introduction}

In the last two decades, corporate governance has turn out to be one of the significant topics of discussion among academicians, professionals, analyst and etc. Although corporate governance gained attention and focus during this period more than ever before, the financial crisis of 2008/2009 further exposed the significance of corporate governance to the globe (Donker and Zahir, 2008). During the crisis, companies that practice recommended corporate governance measures were found to have higher financial performance. There is no universally accepted definition of corporate governance however; there are as limitless definitions almost as there are many research in the field of corporate governance. Claessens and Yurtoglu, (2013) classified the definition of corporate governance produced by many research into two classifications. The first category of the definitions deals with a collection of behavioral patterns that companies follows in terms of measures such as: growth, performance, financial structure, efficiency, and treatment of stakeholders. They further stated that this category of definition is particularly found in a single country analyses. This class of definition put more emphasis on issues like; how boards of directors functions, ownership concentrations and its relation with company performance, the role of executive compensation in relation to company performance, the relation between labor policies and performance, and issues relating to stockholders rights. On the other hand, the second category of definitions is concerns with the normative structure of corporate governance: that is, the legal (system) framework, financial markets, and factor markets. This encompasses the rules and regulations under which companies operates. This category of definition is particularly found in comparative studies because the studies tend to examine and investigate the differences in the normative framework and its effect on the behavioral patterns of companies, sectors, countries, and others.

\section{$\underline{\text { Suggested Citation }}$}

Karaye, A.B., Büyükkara, G. (2021). The Impact of Corporate Governance on Financial Performance of Companies in Southern Africa, Journal of Business Research-Turk, 13 (2), 1817-1834. 
The most acceptable definitions of corporate governance are those given by Cadbury report and the Organization for Economic Co-operation and Development (OECD). The Cadbury committee report of 1992 defines corporate governance as; a system for directing and controlling business organizations. Later in the year 2000, Sir Adrian Cadbury defined corporate governance as the process of holding balances between economic and social objectives, and between individual and mutual objectives (Cadbury, 2000). Similarly OECD defined corporate governance as; the structure that encompasses the process of designing and allocating company goals, the processes of attaining those goals and performance control (OECD, 1999). A much more detailed definition was updated later to; a collection of affiliations between company's management, its board, its stockholders and other stakeholders, it also offers the configuration that encompasses the process of setting company goals, the way of achieving those goals and performance control (OECD, 2004). In line with these definitions, many researchers and professionals vigorously defined corporate governance.

On the other hand, corporate governance code refers to a collection of principles, standards, or recommendations of best practices, mostly voluntary that include the structure, behavior, duties and responsibilities of the board that is issued by a collective Institution in an economy (Aguilera and CuervoCazurra, 2004; Scholtz and Smit, 2015). Research has shown that good application of corporate governance recommended principles and codes results in better financial performance (Jensen and Meckling 1976; Klapper and Love 2004; Munisi and Randøy, 2013; Arora and Bodhanwala, 2018).

The shareholder model of corporate governance explicitly stated that, the main objective of a company is to maximize shareholder wealth through achieving a higher financial performance (Kyereboah-Coleman, 2007). Generally, a good corporate governance should encourage investors wealth creation, reduce fraud which consequently reduce cost of capital, restrict managerial shirking, lower company risk, protect minority shareholders, improve stock market liquidity and foster a good relationship between a company and its stakeholder (Donker and Zahir, 2008; Claessens, and Yurtoglu, 2013). The understanding of corporate governance structures is vital to every economy, because it directly affect the efficacy of the market for corporate control. Corporate governance mechanisms are classified into either: internal which include; matters relating to the board of directors and the ownership composition of a company, or external mechanisms which include; the market for corporate control and the institutional and/or legal regulatory system in a country (Aggarwal and Williamson, 2006). The institutional and legal aspect of corporate governance is responsible for the provision of corporate governance code of best practice.

Most of the recommended codes of corporate governance were originally designed in developed countries. Our focus in this research is the Southern Africa region of Africa. Although all the countries in this region are developing countries, their recommended codes of corporate governance were derived from those that were originally designed in developed nations like The UK and USA (Munisi and Randøy, 2013). Although the features of developed economies like USA, UK and etc. differs from those of developing countries in Southern Africa, their codes where derived mostly from developed economies in order to attract foreign investment. Developing countries are considered to be those countries that are in the mid-stream of developing. These countries are commonly located in Africa, Latin America and Asia (Waweru and Uliana, 2005).

There are a lot of literature regarding corporate governance from diverse disciplines by various researchers and intellectuals in the field of Finance, Law, Economics, Accounting, Management and Sociology (Kiel and Nicholson, 2003). Nonetheless, majority of these research were carried out in developed nations. There are inadequate empirical cross-country studies on corporate governance practices amongst African companies (Nganga et al., 2003; Kyereboah-Coleman, 2007; Abor, J. and Fiador, 2013; Munisi, and Randoy, 2013). Most of the studies that investigate the correlation between corporate governance and company's financial performance in Africa are single-country studies. Very few studies focus on examining more than one country simultaneously.

Therefore, the purpose of this study is to examine the effect of corporate governance mechanisms on the financial performance of listed companies with special focus on Southern Africa. The findings show a positive relationship between corporate governance index and companies financial performance from the result of 
both POLS and GMM. The relationship between sub-indexes of corporate governance and financial performance was also examined. The findings show that after controlling of selection bias and endogeneity, out of the four sub-indexes that we construct; the board committees, shareholders right and disclosure subindexes are positive and significantly related to financial performance, while the attributes under board of directors' sub-index are positive but insignificantly related to financial performance in the Southern African region.

To the best of our knowledge, this study is the first research that studies the impact of corporate governance on the financial performance in Southern Africa. Therefore, this study will contribute to the corporate governance literature by focusing on identifying the extent to which corporate governance mechanisms represented by principles of corporate governance and codes of best practice are exercised by listed companies across Southern Africa and their effect on financial performance. This study wills also further the literature by accessing which corporate governance mechanisms accounts for higher financial performance.

This study is organized as follows: section 2 examines the literature review on corporate governance practice in Africa with a special emphasis on Southern Africa region together with the statement of research problem. It also describes our corporate governance index and hypothesis. Section 3 shows the methodology applied in this research. Section 4 exhibits the findings and discussion of the results. Section 5 exhibit robustness and discussion of the result and finally section 6 comprises of the conclusion the study.

\section{Literature Review}

\subsection{Statement of Research Problem and The Relevance of Corporate Governance in Southern Africa.}

Earlier studies in Africa also show that effective corporate governance encourages corporate responsibility and enhances companies' goodwill, which eventually becomes a foundation toward attracting local and foreign investors (Rossouw, 2005). Good corporate governance is also perceived as deterrence and restrain toward corruption and immoral business praxes that is perceived as a symbol of Africa's business aura (Armstrong, 2003). Africa in general is conventionally perceived as a high-risk zone by international investors. It is often believe that African countries are featured by weak institutional environment, weak and corrupt judicial system, macro-economic instability, trade restrictions, and high government intervention on business activities (Okeahalam and Akinboade, 2003). Although, after the 2008/2009 global financial crises many reforms were put in place to improve good governance, some African countries still possess underdeveloped capital markets, and in some cases the markets were established around the 1990s or early 2000s. The stock exchange markets of African countries faced a number of problems that hinders the growth, development and full control of the activities of its listed companies. The small number and small market capitalization of listed companies in the markets are the manifestation of past and severe setbacks that the markets faced. These setbacks consist of liquidity challenges, low trading volume, low demand for securities and a significant hesitation in the creation of regulatory bodies for the market (Karaye, 2014). Even when good regulatory bodies exist, administration of laws and regulations are often below the standards (Okpara, 2011). Additionally, most of these economies were either distinguished as very bureaucratic or politically corrupt.

South Africa is in the fore front of corporate governance in Africa. South Africa owns the second largest economy in Africa and it has the largest and the oldest stock exchange market in Africa. Unlike the rest of the Southern African nations, South Africa has comparatively firm financial and regulatory organizations (Ntim, 2009). South Africa is arguably the leader in establishing sound corporate governance guidelines that served as a benchmark for other countries in both the region and Africa as a whole. Although South Africa is a developing country the King Report I, II, III and IV were also derived from principles and codes of corporate governance given by OECD and other developed countries like the UK and USA. However, the country has the necessary resources to enforce these governance guideline, thus becoming the focal point for inspecting the extent in which corporate governance mechanisms are adopted in Africa (Vaughn and Ryan, 2006; Mangena and Chamisa, 2008; Waweru, 2014). In contrast, the other countries in the region are less developed than South Africa; they have fewer resources, less efficient institutions and a weaker legal system. However, countries that have weak institutional and legal system present an opportunity for companies to voluntarily apply corporate governance recommendation in other to differentiate themselves from others. Klapper and 


\section{A.B. Karaye - G. Büyükkara 13/2 (2021) 1817-1834}

Love (2004) also stated that company level corporate governance is extra crucial in economies that have weak legal systems.

Corporate governance practices in both national and company levels are considered as pivotal factors that draws the attention of potential domestic and international investors (Claessens, 2006). Despite the importance of corporate governance on company performance, Prior empirical studies failed to look at Southern Africa as a region but rather they focus on single country analyses. African countries are classified under two main models of corporate governance; those that apply the Anglo-US model often refer to as "common law countries" and those that apply the Europe-Asia Model often known as "civil law countries" (Munisi and Randoy, 2013). The common law countries often have English language as their official language with the exception of Egypt, and they are mostly situated in the southern, eastern, and western Africa regions, with the only exceptions of Egypt from North Africa. The civil law countries in Africa are mostly the countries that have French or Portuguese as official language. They are mostly situated in central, western and northern Africa (Rossouw, 2005).

The focus of this research is mainly on the common law countries of Southern Africa region. This is because Southern Africa is the region that has the highest number of common law countries in Africa. There are 10 countries in Southern Africa, out of which Angola and Mozambique are civil law countries. Out of the eight common law countries, Lesotho's LSE stock market was established in 2014, and the Swaziland's Eswatini stock exchange only have total number of eight listed companies as at year end 2019. Some of the companies where even listed after 2013. Therefore, considering that we only use the data of companies that published annual reports from 2013 to 2019, the sample of this study only include six common law countries of the Southern Africa region namely; Botswana, Malawi, Namibia, South Africa, Zambia and Zimbabwe.

\subsection{Development of Corporate Governance Index (CGI) and the Hypotheses of the Study}

According to Aggarwal and Williamson, (2006) markets are rewarding companies that implement better corporate governance, thus, understanding of corporate governance mechanism, principles and structures is significant to every economy because it; directly affect the efficacy and potency of the market for corporate control, impact on company valuation and performance, and in turn impact on the economy of a country. The objective of corporate governance is transparency, fairness and ample disclosures to company's stakeholders (Arora and Bodhanwala, 2018). Corporate governance mechanism must also foster accountability, independence, transparency, and integrity (Claessens and Yurtoglu, 2013). Most of the few existing crosscountry studies on corporate governance in Africa separately analyzed the influence of internal corporate governance mechanisms like; ownership concentration, board compositions, board committees and others, on company performance. Yet, these mechanisms do not work in isolation; rather they work in tandem thus complementing each other (Donker and Zaher, 2008). Very few studies used corporate governance index in their analyses to capture all the important variables of corporate governance in Africa.

At this juncture, it is important to note that; we did not find any study that uses either corporate governance index or isolated corporate governance internal mechanisms to examine the effect of corporate governance on financial performance of companies in Southern African as a region.

As corporate governance laws, regulation and priorities vary from one model to another, it also varies from one country to another and from one continent to another. Therefore corporate governance is not a "one size fits all" issue. As such, there is no standard corporate governance index that is used to measure corporate governance mechanisms (Leal and Carvalhal-da-Silva, 2005; Hassan, 2012; Claessens, and Yurtoglu, 2013; Munisi and Randoy, 2013; Arora and Bodhanwala, 2018). Accordingly we construct our corporate governance index by first reviewing previous studies that used corporate governance index in order to handpick the most significant items to be included in our index. These studies include: Black et al, (2005); Carvalhal-da-Silva and Leal, (2005); Aggarwal and Williamson (2006); Shen and Chih (2007); Cheung et al, (2008); Donker and Zahir (2008); Garay and González, (2008); Balasubramanian at al, (2010); Renders et al, (2010); Ammann et al, (2011); Hassan (2012); Munisi and Randoy, 2013; Waweru (2014); Arora and Bodhanwala, (2018). 
In reference to these studies, coupled with reviewing the codes of corporate governance of the economies in Southern Africa, we construct a corporate governance index that comprises of four dimensions of corporate governance mechanisms at company level namely; Board of Directors, Board Committees, Shareholders Right and Disclosure. Although there are many variables that signal good governance, these are the most important mechanisms that signal good corporate governance. We make each of the above mentioned mechanisms a sub-index consisting of several items under it that helps to explain whether the mechanism is applied as recommended by corporate governance principle and codes of best practice or not. Like most of the research, this study includes only items that can be objectively assessed from annual reports of the companies without the need for any interview or further survey. The items were assigned points. If an item is applied by a company one (1) point is assign to the item and if the company did not provide any information regarding the item in its annual report zero (0) point is assign to the item. This is because companies tend to report on corporate governance measures that they implemented and keep silence on those that they did not adopt (Doidge et al, 2007; Ammann et al, 2011). The total amount of items under each sub-index was fixed in a manner that it is neither too confined, to the extent that it will not describe the multivariate characteristics of corporate governance, nor too voluminous that it will make data collection extremely problematic.

Board of directors' sub-index tries to grasp the characteristics of the board such as; board independence, board composition, transparency, its size, its functions, responsibilities and how it perform its duties. Board of directors is arguable the most crucial corporate governance internal mechanism. Board features like; separation of the position of Chairman of board and CEO, ratio of independent non-executive directors, and frequency of board meetings are also considered to be pivotal to the success of corporate governance in every company (Fama, 1980; Kiel and Nicholson, 2003; Aguilera, and Cuervo-Cazurra, 2004; Mangena and Chamisa, 2008; Waweru, 2014; Arora and Bodhanwala, 2018).

Board committees are also considered to be a very significant aspect of the board in carrying its fiduciary duties. The most important board committee is the Audit committee. This committee is crucial in ensuring the integrity of financial reporting and internal financial controls. Audit committee is very crucial to the level that some countries (for e.g. Italy) even oblige companies to create a distinct board of auditors. The audit committee should contain the majority of Independent directors. It main purpose should be to guarantee that the management of a company delivers adequate and honest information regarding all corporate activities financial or otherwise to regulatory authorities and other stakeholders in accordance with laws and regulations (Balasubramanian et al., 2010; Engel et al, 2010; Sener and Karaye, 2014). While in most companies audit committee's function include risk assessment and evaluation, some companies, sectors and countries require a separate risk committee. Other important committees include; Remuneration, Nomination and Corporate governance committees.

Protection of shareholders right is also one of the most significant corporate governance principles. Berle and Means (1932) elucidated that; the continuous expansion of companies leads to the disconnection between ownership and control of companies. However, recent findings show that the Berle and Means (1932) "theory" of dispersed ownership does not reflect the case in developing countries. Developing countries have a high ownership concentration and majorities of companies are owned by small group of institutional investors and group of families (Wei, 2007). When substantial shareholders control the decisions in a company, their policies may result in the expropriation of minority shareholders' capital. Therefore, the existence of majority controlling stockholders in a company may create a conflict of interest between majority and the minority stockholders. In countries where there is a high ownership concentration, the purpose of corporate governance regulation is to decrease the degree of agency problems between majority and minority stockholders, and between stockholders and creditors (Sener and Karaye, 2015). Other issues under this sub-index include; the relationship between the voting and non-voting shareholders, Equal and just treatment of shareholders, voting rights and others.

Disclosures of company's significant financial and non-financial information represent how transparent a company is. Transparency signifies the degree in which disclosed financial and non-financial information truly reflect how company's managers discharge their fiduciary duties and responsibilities in a manner that is understandable by stakeholders (Barth and Schipper, 2008). Disclosure and transparency of companies' 
significant information is nothing short of public accountability (Sinclair, 1995). Disclosure should include both compliance with the minimum required corporate governance disclosures and also voluntary disclosure of information to all stakeholders (Wei et al, 2008). Greater and transparent disclosure is also assumed to generate higher company performance (Klapper and Love, 2004).

Consequently, our CGI is a comprehensive determinant of company related corporate governance and it reveals various corporate governance features of "best" practice by international standards. Table 3 shows the scores of the corporate governance index and its sub-indexes.

Klapper and Love (2004) indicated that companies can enhance shareholders protection rights by choosing sound independent board, having committees to carry out the significant functions of the board, preventing majority shareholders from exploiting the right of minority shareholders, and increasing statutory and voluntary disclosure. For that reason, the main hypotheses of this research are:

H1: There exist a positive and significant relationship between the corporate governance index and financial performance.

H2: All the corporate governance sub-indexes are equally important in determining the relationship between corporate governance and financial performance.

\section{Methodology}

\subsection{Population and Sampling}

The data used in this study were hand collected from the annual reports of the companies listed in stock exchange markets in Southern Africa. However, while, Southern Africa region comprises of both Common law and Civil law countries, this study only consider the common law countries with special focus to the period after the 2008/2009 global financial crises and before the advent of COVID-19 pandemic. The data covers seven (7) years from 2013 to 2019. Companies that did not trade in the span of the full seven years were eliminated. The population of this study is the companies listed in the Southern African common law countries' stock markets. Sample data was collected from the six (6) countries' listed companies namely; Botswana, Malawi, Namibia, South Africa, Zambia and Zimbabwe. The annual reports were retrieved either from the company's individual website or from www.africanfinancials.com.

Table 1: Summary Panel Data of Observations by Country and Sector.

\begin{tabular}{|c|c|c|c|c|c|c|c|c|}
\hline \multirow[b]{2}{*}{ Sector } & \multicolumn{3}{|c|}{ Countries } & \multirow[b]{2}{*}{ SA } & \multirow[b]{2}{*}{ Zambia } & \multirow[b]{2}{*}{ Zimbabwe } & \multirow[b]{2}{*}{ Total } & \multirow[b]{2}{*}{ Percentage } \\
\hline & Botswana & Malawi & Namibia & & & & & \\
\hline Agriculture & 7 & 0 & 0 & 7 & 7 & 14 & 35 & 6.95 \\
\hline Communication & 0 & 14 & 0 & 7 & 7 & 7 & 35 & 6.95 \\
\hline Construction & 0 & 0 & 0 & 7 & 14 & 14 & 35 & 6.95 \\
\hline Energy & 14 & 0 & 0 & 7 & 14 & 0 & 35 & 6.95 \\
\hline Finance & 14 & 35 & 14 & 7 & 14 & 14 & 98 & 19.45 \\
\hline Health & 0 & 0 & 0 & 7 & 0 & 7 & 14 & 2.79 \\
\hline Manufacturing & 7 & 14 & 21 & 7 & 7 & 14 & 70 & 13.89 \\
\hline Mining & 14 & 0 & 21 & 7 & 7 & 7 & 56 & 11.11 \\
\hline Retail & 7 & 7 & 21 & 7 & 0 & 0 & 42 & 8.30 \\
\hline Services & 7 & 7 & 0 & 7 & 7 & 0 & 28 & 5.57 \\
\hline Tourism & 14 & 7 & 0 & 7 & 7 & 7 & 42 & 8.30 \\
\hline Transportation & 0 & 0 & 7 & 7 & 0 & 0 & 14 & 2.79 \\
\hline Total & 84 & 84 & 84 & 84 & 84 & 84 & 504 & 100 \\
\hline
\end{tabular}

Source: Prepared by the authors.

The sample selection is also an important issue due to the fact that, most studies often only considered the largest companies and/or Non-financial companies. This indicates that a lot of research examined a sample that is truncated in size. To avoid this, in this study the sample encompasses all companies from all sectors. 
This is because the focus here is the full picture of the Southern African region in relation to corporate governance and financial performance regardless of the sectors. Hence, the data comprises of panel data from both financial and non-financial companies.

Table 1 shows the summary of the sampled listed companies used in this study with their respective sectors and countries. The data is a balanced data due to the fact that the number of companies taken from each country is 12 which covered 7 years, making it 84 company-year observation from each country. The total number of the companies in the sample is 504 . The sector with the highest number of companies in the sample is Finance sector which has $19.45 \%$ of the sample with 98 companies. The sectors with the lowest sample are; Health and transportation, from which each sector have 14 companies which consist of $2.79 \%$ of the sample. Agriculture, Communication, Construction and Energy sectors have 35 companies each consisting 6.95\% of the sample. Manufacturing sector consist of 70 companies making it the second largest sector with $13.89 \%$ of the sample. Mining, Retail and Services sectors consist of 56 companies (11.11\%) of the sample, $42(8.30 \%)$, and $28(5.57 \%)$ companies, respectively.

The reason that finance sector has the majority of companies in the sample is due to the fact that; only companies that provide full annual report each year from the period of 2013 to 2019 were included. Furthermore, our classification of finance sector consists of banks, insurance companies, investment companies and other financial services. Additionally, in Malawi, more than $42 \%$ of the listed companies in the market are in finance sector. Moreover, it is well known that; since after the Lehman Brothers bankruptcy and the 2008/2009 global financial crises, finance sector is arguably the most scrutinize sector in relation to issues of corporate governance and financial reporting. Therefore, it is natural to be faced with a situation in which the majority of the companies that have full long-term financial reporting fall within this sector.

\subsection{Research Model and Variables}

In this study, accounting measures of performance were employed to determine financial performance namely; Return on Equity (ROE) and Return on Asset (ROA). Return on Asset (ROA) in this study is defined as profit after interest and tax divided by total assets. This shows how lucrative a company is in relation to its total assets, it display how company's assets are excellently governed by the management. Return on Equity (ROE) is defined as profit after interest and tax divided by owner's equity. This shows how lucrative a company is by displaying how much profit a company makes with the capital of stockholders. The Independent variables of this study are the corporate governance index (CGI) and its sub-indexes. Furthermore, company leverage (LEV), company size (SIZE), company's capital-intensity ratio (CIR), company's age (AGE), and secondary listing (ADR) are employed as control variables because they are reported by many research to have significant influence on financial performance and the practice of corporate governance (Jensen 1986; La Porta et al, 2002; Cheung et al, 2008). Table 2 shows the variables, their codes, type and definition.

Subsequent to the hypotheses developed in Section 3, the data is first analyzed using the following panel data ordinary least squares (OLS) regression models:

$$
\begin{aligned}
& R O A_{i t}=\alpha_{i}+\beta_{1} C G I_{i t}+\beta_{2} C I R_{i t}+\beta_{3} A G E_{i t}+\beta_{4} S I Z E_{i t}+\beta_{5} L E V_{i t}+\beta_{6} A D R_{i t}+\epsilon_{i t} \\
& R O E_{i t}=\alpha_{i}+\beta_{1} C G I_{i t}+\beta_{2} C I R_{i t}+\beta_{3} A G E_{i t}+\beta_{4} S I Z E_{i t}+\beta_{5} L E V_{i t}+\beta_{6} A D R_{i t}+\epsilon_{i t}
\end{aligned}
$$

To find the effect of individual sub-index on financial performance we use the following model:

$$
\begin{aligned}
& R O A_{i t}=\alpha_{i}+\beta_{1} B O S I_{i t}+\beta_{2} B C S I_{i t}+\beta_{3} S H D I_{i t}+\beta_{4} D I S I_{i t}+\beta_{5} C I R_{i t}+\beta_{6} A G E_{i t}+S I Z E_{i t}+\beta_{8} L E V_{i t}+\beta_{9} A D R_{i t}+ \\
& \epsilon_{i t} \quad \text { (3) } \\
& R O E_{i t}=\alpha_{i}+\beta_{1} \text { BOSI }_{i t}+\beta_{2} \text { BCSI }_{i t}+\beta_{3} \text { SHDI }_{i t}+\beta_{4} \text { DISI }_{i t}+\beta_{5} C I R_{i t}+\beta_{6} A G E_{i t} \\
& +\beta_{7} S I Z E_{i t}+\beta_{8} L E V_{i t}+\beta_{9} A D R_{i t}+\epsilon_{i t}
\end{aligned}
$$

This study employs panel data ordinary least square method (POLS) regression analysis to ascertain if the dependent variables are significantly affected by the level of corporate governance. Since in the robustness test dynamic GMM was employed, there is no need to look for fixed or random effects. The effects were taken care of by the dynamic GMM estimators. 
Table 2: Definitions of Variables Used in the Analysis

\begin{tabular}{llll}
\hline Variable Code & Full Name & Variable Type & Variable Description \\
\hline ROA & Return on Assets & Dependent Variable & Profit or loss/Total Assets \\
ROE & Return on Equity & Dependent Variable & Profit or loss/Total Equity \\
CGI & Corporate Governance Index & Independent Variable & Average compliance of CGI \\
BOSI & Board Sub-Index & Independent Variable & Average compliance of BOSI \\
BCSI & Board Committees Sub-Index & Independent Variable & Average compliance of BCSI \\
SHDSI & Shareholders Right Sub-Index & Independent Variable & Average compliance of SHDSI \\
DISI & Disclosure Sub-Index & Independent Variable & Average compliance of DISI \\
CIR & Capital Intensity Ratio & Control Variable & Total Assets / sales or Turnover \\
LEV & Leverage & Control Variable & Total Debt/Total Equity \\
SIZE & Company Size & Control Variable & Logarithm of Total Assets \\
AGE & Company Age & Control Variable & Present year-Establishment year \\
ADR & Secondary Listing & Control Variable & Listed in more than 1 market \\
\hline
\end{tabular}

Source: Prepared by the authors.

\section{Results and discussion of empirical analysis}

\subsection{Descriptive Statistics}

Table 3 displays the level of compliance with each of the Corporate Governance Sub-indexes. In general, the mean of the CGI score across all of the sub-indexes is $70 \%$, where $100 \%$ represent total compliance. This indicates that, on average, companies in Southern African countries comply with more than $70 \%$ of the recommended corporate governance principles and codes of best practice represented by our CGI. The highest observed company-level corporate governance is $100 \%$ compliance, and the lowest is $12 \%$. The table shows that all the companies always report on their financial situation, financial performance and comply with the laws that are mandatory regarding annual reporting or explain the reason for not complying with such law(s) where they choose otherwise. The board of directors' sub-index produces a mean of $76.4 \%$. This implies that, only $76.4 \%$ of what is regard as good corporate governance practices in relation to the effective monitoring of managers, key functions of the board, independence of the board and mix of inside and outside directors is adopted by the companies. Furthermore, while $100 \%$ comply with the law or explain the reason for noncompliance, more than $97 \%$ of the companies' boards fully comply with the law. The table also shows that $98 \%$ of the companies' boards guard the integrity of financial reporting of the companies. Additionally, $95 \%$ of the companies have separate positions of chairperson of the board from CEO. This indicates that almost all of the companies in Southern Africa have a clear separation of the duties and responsibilities between "the monitoring unit" and the management of the company. Additionally, 95\% of the companies have nonexecutive directors present in their boards. However, only $39 \%$ of the boards have the majority independent non-executive directors. These indicates that although most of the boards may have the essential independence to monitor the executive management, much more independence is needed in order to have full, efficient and effective monitoring of the boards in the Southern Africa region. This is also supported from the fact that only $36 \%$ of the boards of the companies manage potential conflicts of interest in the boards.

Table 3: Corporate Governance Index and Compliance

\begin{tabular}{ll}
\hline $\mathbf{N} \quad$ Statement & Average $\%$ \\
\hline Board of Directors sub-Index & 76.4 \\
1. Comply-or-explain principle & 100 \\
2. Shareholder value maximization & 67 \\
3. Long-term viability of the company & 70 \\
4. Good relationship with stakeholders & 86 \\
5. Effective monitoring of management & 78 \\
6. Compliance with laws & 97 \\
7. Guide corporate strategy & 81 \\
8. Monitor and replace key executives & 67
\end{tabular}


9. Review remuneration

10. Manage potential conflicts of interest 36

11. Guard integrity of financial reporting 98

12. Increase effectiveness of governance practices 91

13. Separation of chairman and CEO 95

14. Non-executive directors present 95

15. Majority Independent directors 39

16. Stock options allowed as compensation 30

Board Committees Sub-Index $\quad 50.1$

17. Appointment/Nomination committee 47

18. Remuneration committee 71

19. Audit committee 96

20. Corporate governance committee 23

21. Risk committee 55

22. Appointment committee: propose appointment of directors 44

23. Remuneration committee: recommend remuneration for directors 65

24. Audit committee: report to the board 85

25. Audit committee: appoint auditor and determine audit fee 49

26. Corporate governance committee: meet at least 3 times annually 12

27. Risk committee: meet at least 3 times annually 29

28. Audit committee: hear the company auditors 74

29. Appointment/Nomination committee: chair is independent director 30

30. Remuneration committee: chair is independent director 39

31. Audit committee: chair is independent director 55

32. Corporate Governance committee: chair is independent director 14

Shareholders Right Sub-Index $\quad 64.2$

33. Equal treatment of shareholders 45

34. One share/one vote 27

35. No anti-take-over devices $\quad 97$

36. Proxy voting allowed 83

37. Select new directors 84

38. Participate in decisions concerning fundamental changes 85

39. Decide on distribution of profits 43

40. Ask questions

Disclosure Sub-Index $\quad 94.5$

41. Use International Financial Reporting Standards (IFRS) 99

42. Audited by an independent auditor $\quad 99$

43. Timely disclosure of relevant information 99

$\begin{array}{ll}\text { 44. Financial situation } & 100\end{array}$

45. Financial performance 100

46. Ownership structure 89

47. Corporate governance report 95

48. Relevant interests of directors

49. Composition of board $\quad 97$

50. Remuneration of key executives $\quad 85$

Average Corporate Governance Index $\quad 70$

Source: Researchers' analyses

The Board Committees sub-index mean is $50.1 \%$. The Board Committee sub-index shows that while $96 \%$ of the companies have audit committee in their boards, $71 \%$ have remuneration committee, $55 \%$ have risk committee and $47 \%$ have appointment/nomination committee. However, only $23 \%$ of the companies' boards have corporate governance committee. Furthermore, audit committee, remuneration committee, and appointment/nominating committee have $55 \%, 39 \%$ and $30 \%$ of independent non-executive director as their 
chairperson of the committees, respectively. Overall, these suggest that while the majority of the companies in Southern Africa practices good corporate governance in relation to the audit, recruitment and remuneration functions of the board, the practice of creating a separate independent corporate governance committee in the boards are still scarce in the region. The table also shows that the corporate governance practice relating to board committees varied from one company to another with the minimum score of $12 \%$ and maximum score of $96 \%$.

The mean value of Shareholders right sub-index is $64.2 \%$. This shows that; in southern Africa, on average the rights of shareholders are protected. It also shows that $97 \%$ of the companies in Southern African do not have any anti-take-over devices that are put in place to prevent any hostile take-over. This implies that the companies listed in the Southern Africa markets are free of any restriction for competitive market and corporate governance plays an important role in deciding the future of the companies. The minimum score in this sub-index is $27 \%$ which indicates that only $27 \%$ of the companies fully explain to their shareholders that; in the event of any election during annual general meetings, a shareholder is entitled to one vote for every share held in the company. The table also shows that in $85 \%$ of the companies, the shareholders always participate in decisions concerning any fundamental changes in the companies.

The disclosure sub-index has a $94.5 \%$ mean value. This is the sub-index with the highest mean value and highest individual CGI scores. There is $100 \%$ disclosure of information regarding financial situation and financial performance of the companies. At the same time, there exist $99 \%$ disclosure on the use of International Financial Reporting Standards (IFRS), Independent auditor, and the timely disclosure of relevant information to the public. $95 \%$ of the companies also disclose a separate corporate governance report in their annual reports. The minimum score in this sub-index relates to the disclosure of relevant interest of directors, which shows that only $82 \%$ of the companies disclose their directors share holdings in the company. This suggest that the companies in Southern Africa have a good culture of disclosing relevant and timely information to the public, so that stakeholders can make informed decision regarding the companies.

Table 4: Summary descriptive statistics of Variables

\begin{tabular}{llllll}
\hline Variables & Observations & Mean & Std. Dev. & Minimum & Maximum \\
ROA & 504 & -0.005 & 1.4986 & -33.344 & 0.9128 \\
ROE & 504 & 0.0899 & 0.7028 & -9.2346 & 2.2314 \\
CGI & 504 & 0.7000 & 0.1584 & 0.12 & 0.96 \\
LEV & 504 & 1.0896 & 13.269 & 0 & 295.10 \\
SIZE & 504 & 8.2088 & 0.9508 & 5.4163 & 10.852 \\
AGE & 504 & 1.6284 & 0.3377 & 0.4771 & 2.2552 \\
CIR & 504 & 0.5460 & 0.3709 & 0 & 4.3366 \\
ADR & 504 & 0.3174 & 0.4659 & 0 & 1 \\
BOSI & 504 & 76.14 & 0.1905 & 6.25 & 100 \\
BCSI & 504 & 50.48 & 0.2492 & 0 & 100 \\
SHDSI & 504 & 64.21 & 0.2153 & 12.5 & 100 \\
DISI & 504 & 94.50 & 0.0981 & 30.00 & 100 \\
\hline
\end{tabular}

Source: Researchers' analyses

Table 4 shows the summary descriptive statistics of the variable employed in this study. From the 504 observations, CGI constitute a minimum figure of $12 \%$ and maximum of $96 \%$ and a mean of $70 \%$. This implies that the company with the least compliance to our corporate governance index has a least score of $12 \%$ while the company with the highest compliance to the corporate governance index has $96 \%$ compliance. This further compliments the result of average Corporate Governance Index score in table 3. The standard deviation of CGI is approximately $16 \%$. This means that the compliance to corporate governance index can deviate from mean to both sides by $16 \%$. The table additionally reveals that on average, the companies incurred a loss in Return on Asset (ROA) of about $0.5 \%$. However, the companies have a mean average of Return on Equity (ROE) of about $9 \%$. 


\subsection{The Relationship between corporate governance and financial performance}

Table 5 represents the main analysis; showing the coefficients for the impact of corporate governance index on company financial performance measures. Table 5 shows the result of the regression analyses from model (1) and model (2) created in section 3. The regression was executed using the "Robust" command in STATA 16. This command automatically eliminates heteroskedasticity and multicollinearity problems. As such, there is no need to check for heteroskedasticity and multicollinearity. The VIF result was less 2, suggesting that multicollinearity does not pose a critical problem into the data (Waweru 2014; Tabachnick and Fidell, 1996). The F-values of the two models are significant at $1 \%$ level; this means that the models did not bear specification bias (Ranti, 2011). Furthermore, from the ROA model (model 1), the $\mathrm{R}^{2}$ indicates that more than $13 \%$ of change in ROA is accounted for by the independent variable. The regression from model (2) indicates that only $9.5 \%$ of change in ROE is accounted for by the independent variable. Regarding the explanatory variables, the two regression results from model (1) and (2) indicates that there is a significant positive relationship between company financial performance indicators and the corporate governance index in Southern Africa at $1 \%$ significance level.

Table 5: Relation between corporate governance index and company performance POLS regressions

\begin{tabular}{lcc}
\hline Dependent variable & ROA & ROE \\
\hline Corporate Governance Index & $0.7071^{* * *}$ & $0.6268^{* * *}$ \\
& $(2.81)$ & $(2.68)$ \\
Capital Intensity Ratio (CIR) & 0.0813 & -0.0594 \\
& $(1.17)$ & $(-0.63)$ \\
Company Age (AGE) & -0.0041 & $-0.5215^{* *}$ \\
& $(-0.02)$ & $(-2.43)$ \\
Company Size (SIZE) & $-0.3069^{* * *}$ & $-0.1755^{*}$ \\
& $(-3.60)$ & $(-1.90)$ \\
Leverage (LEV) & $-0.1420^{* * *}$ & 0.0657 \\
& $(-2.99)$ & $(1.34)$ \\
Secondary Listing (ADR) & $0.4831^{* * *}$ & $0.6062^{* * *}$ \\
& $(3.76)$ & $(4.45)$ \\
No. of Observations & 311 & 311 \\
R-Squared & 0.136 & 0.095 \\
F Statistic & 6.111 & 3.949 \\
\hline
\end{tabular}

Source: Researchers' analyses

***Significant at the 0.01 level

** Significant at the 0.05 level

* Significant at the 0.10 level

In addition, the result also shows a significant negative relationship between the control variable company age and ROE at $5 \%$ level. There is also a significant negative relationship between company size and both ROA and $\mathrm{ROE}$ at $1 \%$ and $10 \%$ respectively. This further support the fact that; younger companies are in the growth stage of their life cycle, thus, they possesses more intangible assets as such they have higher financial performance (Balasubramanian et al, 2010). The result also shows that leverage has significant negative relationship with ROA. This indicates that, the companies with low level of leverage have a higher financial performance than the highly levered companies. Lastly, the result also shows the existence of a significant relationship between secondary listing (ADR) and the two financial performance indicators of this study. This is consistent with the result of Doidge et al, (2007), which finds that companies that are secondary listed in the US markets are valued higher than those that are only listed in one market. This result further complements to the fact that companies listed in more than one market are more open to the compliance of corporate governance principles and regulation and therefore are more likely to have a higher financial performance.

Table 6: POLS regressions of sub-indexes 


\begin{tabular}{lcccc}
\hline Dependent variable & $\begin{array}{c}\text { Board of } \\
\text { directors }\end{array}$ & $\begin{array}{c}\text { Board } \\
\text { Committees }\end{array}$ & $\begin{array}{c}\text { Shareholders' } \\
\text { Rights }\end{array}$ & Disclosure \\
\hline Panel A: dependent variable (ROA) & & & & \\
Coefficient of sub-index & $0.5646^{* * *}$ & 0.1292 & $0.6039^{* * *}$ & 0.1135 \\
& $(2.67)$ & $(0.86)$ & $(4.04)$ & $(0.25)$ \\
No. of Observations & 311 & 302 & 311 & 311 \\
R-Squared & 0.132 & 0.118 & 0.173 & 0.114 \\
F Statistic & 6.083 & 5.685 & 7.170 & 5.978 \\
& & & & \\
Panel B: dependent variable (ROE) & & & & -0.2608 \\
Coefficient of sub-index & $0.4895^{* *}$ & 0.1491 & $0.5867^{* * *}$ & $(-0.58)$ \\
& $(2.40)$ & $(0.98)$ & $(3.73)$ & 311 \\
No. of Observations & 311 & 302 & 311 & 0.080 \\
R-Squared & 0.092 & 0.087 & 0.131 & 3.383 \\
F Statistic & 4.129 & 3.599 & 4.441 & \\
\hline
\end{tabular}

Source: Researchers' analyses

***Significant at the 0.01 level

** Significant at the 0.05 level

* Significant at the 0.10 level

Table 6 shows the regressions of sub-indexes from model (3) and (4). Although table 5 already shows that the CGI has a positive significant effect on the financial performance indicators, table 6 shows which of the subindexes account for the positive and significant effect on financial performance. It can be observed that both Panel A and B results shows that; the positive significant relationship between the CGI and the financial performance indicators is only accounted for by board of directors sub-index and shareholders rights subindex mostly at $1 \%$ significant level.

\section{Robustness check and discussion}

Himmelberg et al, (1999) stated that during analysis, it is often problematic to understand whether causality between performance and corporate governance practices exist or if the result obtained from the analysis is affected by unobserved heterogeneity. Unobserved heterogeneity can be as a result of company specific factors that are not included in the analyses (Leal and Carvalhal-da-Silva, 2005). In this study, we control for both sample-selection and unobserved bias. Leal and Carvalhal-da-Silva, (2005); Klapper and Love (2004); Black et al, (2003); Himmelberg at al, (1999), among others, argue that when financial performances are measured in terms of corporate governance using panel data, endogeneity problem may arises. The endogeneity arises where performance and more specifically poor performance results in changes in corporate governance practice, and therefore, the change in the practice of good corporate governance may cause better performance, and this will in turn results in a two-way causality problem (Renders et al, 2010). Another source of endogeneity can be attributed to dynamic endogeneity. This is a situation where there is simultaneity, unobservable heterogeneity and the probability that the present values of the corporate governance variables are as a result of previous year(s) company's financial performance (Munisi and Randøy, 2013; Wintoki et al, 2012). Therefore, results that have endogeneity problem have a high possibility of been biased and encompasses unreliable values that renders reliable interpretations almost impossible, hence the result cannot be trusted (Munisi and Randøy, 2013; Roberts \&Whited, 2011). As such, for more reliable and robust result, it is necessary to control for endogeneity. For this purpose, robustness check was conducted for the regression results obtained in this study.

For the robustness of our analyses, difference GMM was employed using the Xtabound2 command in Stata developed by Roodman (2009). Instrumental variables approach can be a hectic job; this is due to the fact that suitable instruments for corporate governance are scarce and difficult to implement (Ammann et al, 2011). GMM is a very effective tool in alleviating endogeneity problem especially in situations where finding instruments that are capable of reducing endogeneity become tedious (Arellano \& Bond, 1991; Arellano \& Bover, 1995; Blundell \& Bond, 1998). GMM can transform OLS and fixed effects result into effective and 
reliable results by including company specific fixed effects so that fixed unobservable heterogeneity is dealt with. GMM also allow the use of lagged period so as to control for the effect of previous year(s) performance on present corporate governance. GMM can also be used to control for simultaneity by including some company specific variables as instrumental variables (Munisi and Randøy, 2013; Wintoki et al, 2012). Therefore, Xtabond 2 was employed to use the lagged levels of period T-2 of the independent and dependent values as instruments to control for simultaneity, reverse causality and dynamic endogeneity. As such, all explanatory variables were treated as endogenous and their lag T-2 was used as instruments. At the same time, year, industry and country dummies were utilized as exogenous variables. This is because in some instances each industry may be in a different stage of life circle, thus presenting different set of elements that can determine the company financial performance. Hence, it must be controlled for. On the other hand, year dummy variables help to control for macroeconomic effects throughout the periods (Leal and Carvalhal-daSilva, 2005).

Table 7: Relation between corporate governance index and company performance

\begin{tabular}{lcc}
\hline Dependent variable & ROA & ROE \\
\hline CGI & $2.1650^{*}$ & $2.1315^{* *}$ \\
& $(1.99)$ & $(2.06)$ \\
CIR & $-1.2867^{* * *}$ & $-1.2394^{* * *}$ \\
& $(-4.62)$ & $-6.77)$ \\
AGE & 1.8311 & 5.2431 \\
& $(0.41)$ & $(1.09)$ \\
SIZE & $-0.8017^{* * *}$ & $-0.6989^{* * *}$ \\
& $(-3.28)$ & $(-2.44)$ \\
LEV & -.06321 & 0.2299 \\
& $(-0.23)$ & $(0.77)$ \\
ROAt-1 & 0.1498 & \\
& $(0.86)$ & 0.0061 \\
ROEt-1 & & $(0.05)$ \\
AR (1) test (p-value) & & 0.116 \\
AR (2) test (p-value) & 0.090 & 0.308 \\
Hansen test of over-identification (p-value) & 0.491 & 0.257 \\
Observations & 0.391 & 205 \\
\hline
\end{tabular}

Source: Researchers' analyses

This is the result of the panel data estimates using difference GMM with their t-statistics in parentheses. The explanatory variables are employed as endogenous employing all lags to period $t-2$ as instruments. Country, industry and year dummies are employed as exogenous variables. A "collapse" option in Stata 16 is use to limit instrument proliferation and one-step robust standard errors are used. AR (1) and AR (2) are tests of first-order and second-order serial correlation in the first-differenced residuals, under the null hypothesis of no serial correlation. The Hansen test of over-identification was executed under the null hypothesis that all instruments are valid.

***Significant at the 0.01 level

** Significant at the 0.05 level

* Significant at the 0.10 level

Table 7 shows the relationship between corporate governance index and financial performance of companies after controlling for endogeneity. The result indicate a positive and significant relationship between the CGI and both ROA $(t=1.99, p<0.10)$ and $\operatorname{ROE}(t=2.06, p<0.05)$. Therefore, the first hypothesis H1 is accepted. This finding is coherent with that of Klapper and Love (2004); Munisi and Randøy, (2013); Arora and Bodhanwala, (2018). Furthermore, Capital Intensity ratio is also found to have negative and significant association with both ROA and ROE at $1 \%$ significance level. This suggests that; companies that have more fixed capital as a fraction of their revenue have lower financial performance. This is reasonable because companies that have more fixed capital are likely to have less intangible capital, and therefore, intangible capital is expected to have a positive effect on financial performance (Black et al, 2005). The result also shows that company size also has a negative and significant relation with the financial performance indicators. 
Table 8 shows the relationship between corporate governance sub-indexes and financial performance of companies after controlling for endogeneity. Panel A present the results when financial performance is measured by ROA and Panel B present that of ROE. It can be seen that Board Committees sub-index is positive and significantly related to both ROA and ROE at $5 \%$ significance level. Disclosure sub-index is also positive and significantly related to both ROA and ROE at 10\% significance level. Additionally, Shareholders Rights sub-index is also positive and significantly associated with ROE at $5 \%$ significance level. These results implies that implementing good corporate governance measures and practices that are related to only board committees, full disclosure and shareholders right protection are of paramount importance in improving the financial performance of companies in Southern Africa. As such, hypothesis H2 is rejected because even though board of directors' sub-index is positive but it is insignificantly associated with performance measures. Hence, some sub-indexes are more significant than others.

Table 8: Relation between corporate governance sub-indexes and company performance

\begin{tabular}{lcccc}
\hline Dependent variable & $\begin{array}{c}\text { Board of } \\
\text { directors }\end{array}$ & $\begin{array}{c}\text { Board } \\
\text { Committees }\end{array}$ & $\begin{array}{c}\text { Shareholders } \\
\text { Rights }\end{array}$ & Disclosure \\
\hline Panel A: dependent variable (ROA) & & & & \\
Coefficient of sub-index & 0.1496 & $1.7792^{* *}$ & 1.1298 & $2.5409^{*}$ \\
& $(0.18)$ & $(2.31)$ & $(1.57)$ & $(1.87)$ \\
ROAt-1 & 0.1385 & 0.1462 & 0.1162 & 0.1123 \\
& $(0.78)$ & $(0.87)$ & $(0.74)$ & $(0.67)$ \\
No. of Observations & 207 & 207 & 207 & 207 \\
AR (1) test (p-value) & 0.098 & 0.093 & 0.101 & 0.110 \\
AR (2) test (p-value) & 0.372 & 0.647 & 0.231 & 0.594 \\
Hansen test of over-identification (p-value) & 0.586 & 0.268 & 0.396 & 0.378 \\
& & & & \\
Panel B: dependent variable (ROE) & & & & \\
Coefficient of sub-index & 0.1653 & $1.6284^{* *}$ & $1.4123^{* *}$ & $2.2118^{*}$ \\
& $(0.22)$ & $(2.13)$ & $(2.08)$ & $(1.78)$ \\
ROEt-1 & -0.0055 & -0.0193 & 0.0326 & -0.0412 \\
& $(0.04)$ & $(-0.15)$ & $(0.24)$ & $(-0.33)$ \\
No. of Observations & 205 & 205 & 205 & 205 \\
AR (1) test (p-value) & 0.143 & 0.139 & 0.090 & 0.185 \\
AR (2) test (p-value) & 0.289 & 0.512 & 0.202 & 0.553 \\
Hansen test of over-identification (p-value) & 0.457 & 0.286 & 0.311 & 0.489 \\
\hline
\end{tabular}

Source: Researchers' analyses

To summarize the overall result, while the impact of corporate governance on financial performance is found to be positive and significant, the sub-indexes are not equally important in explaining the positive impact that corporate governance have on financial performance of companies in Southern Africa.

\section{Conclusion}

The purpose of this study is to investigate the impact of corporate governance on financial performance by examining the compliance of companies with good corporate governance practices in Southern African region. In the process, individual companies' corporate governance practices were reviewed by constructing a CGI that is appropriate to the Southern African listed companies. The relation between companies' CGI scores and its accounting measures of financial performance (ROA and ROE) were analyzed after controlling for sample bias and endogeneity. We also investigate which of the sub-indexes of the corporate governance index are profound in clarifying the extent of relationship that exists between corporate governance and financial performance. The findings show that companies in Southern African countries generally conform to the recommended corporate governance best practices. The findings from both the POLS and the dynamic GMM results indicate that the corporate governance index score has a positive and significant relationship with the companies' financial performance measures. Furthermore, the findings also indicate that not all the practices 
have significant influence on company's financial performance. In particular, Board committees sub-index, Shareholders right sub-index and Disclosure sub-index are positive and significantly related to financial performance measured by ROA and ROE.

\subsection{Implication:}

The findings of this study can be a significant source of information to both the King Committee of South Africa and other corporate governance regulatory bodies in Southern Africa countries, in their endeavor to; enhance corporate governance regulations, practices, reduce corporate bankruptcies and protect the welfare of minority stockholders. Corporate governance regulators may use the findings of this study to suggest areas where improvements should be concentrated in the region. Regulators should put more emphasis on issues related to Shareholders rights, Board committees and disclosure requirements. The findings are also useful for companies in Southern Africa in determining what corporate governance measures to prioritize and also in the process of the preparation of annual financial statements. Existing and potential investors can use the results of this study to better understand corporate governance practice behavior of listed companies in Southern Africa, and thereby make more informed investment decisions. The findings will also help foreign investors both within and outside Africa in making an informed investment decision, especially after the African Continental Free Trade Agreement (AFCFTA) that came into force on 1st January 2021.

Conclusively, while, Africa comprises of both Common law and Civil law countries, this study is limited to only common law countries of Southern Africa region and for the period after the 2008/2009 global financial crises and before the advent of COVID-19. Hence, future studies are advised to focus on civil law countries in the region. Future studies can also empirically compare common law and civil law countries in the region. The study only uses two of the accounting based financial performance measures; Return on Assets (ROA) and Return on Equity (ROE), thus it did not take into account the market based performance measures. Accordingly, future studies are also advised to include both accounting and market based performance measures to measure the effect of corporate governance performance measures in the Southern Africa. It is also advised that future studies should focus on the impact of Covid-19 crisis on corporate governance of companies for the years 2020-2021 in Africa, as well the financial performance of the companies using ROE, ROA and others.

\section{References}

Abor, J. \& Fiador, V. (2013). Does corporate governance explain dividend policy in Sub-Saharan Africa? International Journal of Law and Management, 55(3), 201-225. 


\section{A.B. Karaye - G. Büyükkara 13/2 (2021) 1817-1834}

Aggarwal, R. \& Williamson, R. (2006), Did new regulations target the relevant corporate governance attributes?, available at: https://ssrn.com/abstract=859264 (accessed: 5 June 2019)

Aguilera, R. V., \& Cuervo-Cazurra, A. (2004). Codes of good governance worldwide: What is the trigger? Organization Studies, 25, 415-443.

Ammann, M., Oescha, D., \& Schmid M. M. (2011). Corporate Governance and Firm Value: International Evidence. Journal of Empirical Finance, 18, 36-55.

Arellano, M., \& Bond, S. (1991). Some tests of specification for panel data: Monte Carlo evidence and an application to employment equations. Review of Economic Studies, 58, 277-297.

Arellano, M., \& Bover, O. (1995). Another look at the instrumental variable estimation of error-components models. Journal of Econometrics, 68, 29-51.

Armstrong, P. (2003). Status report on corporate governance reform in Africa, Johannesburg, South Africa, Pan-African Consultative Forum on Corporate Governance.

Arora, A. \& Bodhanwala, S. (2018). Relationship between Corporate Governance Index and Firm Performance: Indian Evidence. Global Business Review 19(3) 675-689.

Balasubramanian, B., Black, B. S., \& Khanna, V. (2010). The Relation between Firm-Level Corporate Governance and Market Value: a Study of India. Law \& Economics, 10, 1-29.

Barth, M.E. \& Schipper, K. (2008). Financial reporting transparency. Journal of Accounting Auditing and Finance, 23(2), 73-190.

Berle, A., \& G. Means. (1932). The Modern Corporation and Private Property, New York, MacMillan.

Black, B., Love, I. \& Rachinsky, A. (2006). Corporate governance indices and firm's market values: Time series evidence from Russia. Emerging Markets Review, 7(4), 361-379.

Blundell, R., \& Bond, S. (1998). Initial conditions and moment restrictions in dynamic panel data models. Journal of Econometrics, 87, 115-143.

Cadbury, A. (1992). Report of the Committee on the Financial Aspects of Corporate Governance, London, Gee Publishing.

Cadbury, A. (2000). The Corporate Governance Agenda. Corporate Governance, 8, 7-15.

Carvalhal-da-Silva, A. L. \& Leal, R.P.C. (2005). Corporate Governance Index, Firm Valuation and Performance in Brazil. Revista Brasileira de Financas, 3(1), 1-18.

Cheung,Y., Jiang,P., Limpaphayom, P., \& Lu, T. (2008). Does corporate governance matter in China? China Economic Review, 19, 460-479.

Claessens, S. (2006). Corporate Governance and Development. The World Bank Research Observer, 21(1), 91-122.

Claessens, B. \& Yurtoglu, B. (2013). Corporate governance in emerging markets: A survey. Emerging Markets Review, 15, 1-33.

Doidge, C., Karolyi, G., \& Stulz, R. (2007). Why do countries matter so much for corporate governance? Journal of Financial Economics, 86, 1-39.

Donker, H. \& Zahir, S. (2008). Towards an impartial and effective corporate governance rating system. Corporate Governance International Journal of Business in Society, 8(1), 83-93.

Engel, E., Hayes, R. M., \& Wang, X. (2010). Audit committee compensation and the demand for monitoring of the financial reporting process. Journal of Accounting and Economics, 49, 136-154.

Fama, E.F., (1980). Agency Problems and the Theory of the Firm. Journal of Political Economy, 88, 288-307.

Garay, U. \& González, M. (2008). Corporate Governance and Firm Value: The Case of Venezuela. Corporate Governance an International Review, 16(3), 193-209. 
Hassan, M. (2012). A disclosure index to measure the extent of corporate governance reporting by UAE listed corporations. Journal of Financial Reporting and Accounting, 10(1), 4-33.

Himmelberg, C.P., Hubbard R.G. \& Palia, D. (1999). Understanding the Determinants of Managerial Ownership and the Link between Ownership and Performance. Journal of Financial Economics, 53(3), 353384.

Jensen, M. C. \& Meckling, W. H. (1976). Theory of the firm: Managerial behavior, agency costs and ownership structure. Journal of Financial Economics, 3, 305-360.

Jensen, M. C. (1986). Agency costs of free cash flow, corporate finance, and takeovers. American Economic Review, 76(2), 323-329.

Karaye, A. B. (2014). The Impact of Corporate Governance on the Performance of Listed Companies: The comparison of Nigeria and Turkey. available at: https://tezarsivi.com (accessed: 01 August 2014)

Kiel, G. C. \& Nicholson, G. J. (2003). Board Composition and Corporate Performance: how the Australian experience inform contrasting theories of corporate governance. Corporate Governance An International Review, 11, 189-205.

Klapper, L., \& Love, I. (2004). Corporate Governance, Investor Protection, and Performance in Emerging Markets. Journal of Corporate Finance, 10(5), 703-728.

Kyereboah-Coleman, .A. (2007). Corporate Governance and Shareholder Value Maximization: An African Perspective. Journal of African Development Bank, 350-367.

La Porta, R., De-Silanes, F.L., Shleifer, A. \& Vishny, R.W. (1998). Law and Finance. Journal of Political Economy, 106(6), 1113-1155.

La Porta, R., Lopez-De-Silanes, F., Shleifer, A. \& Vishny, R. (2002). Investor protection and corporate valuation. Journal of Finance, 57(3), 1147-1170.

Leal, R. P. C, \& Carvalhal-da-Silva, A.L., (2005). Corporate Governance and Value in Brazil and in Chile. available at: http//www.iadb.org/res (accessed: 12 April, 2020)

Mangena, M. \& Chamisa, E. (2008). Corporate governance and incidences of listing suspension by the JSE Securities Exchange of South Africa: empirical analysis. The International Journal of Accounting, 43, 28-44.

Munisi, G. \& Randøy, T. (2013). Corporate governance and company performance across Sub-Saharan African countries. Journal of Economics and Business, 70, 92- 110.

Nganga, S., Jain, V. \& Artivor, M. (2003). Corporate governance in Africa: a survey of publicly listed companies. London Business School, London, available at: http//www.africaplc.com/typetool/uploads/main_news/docs/CGiA\%20Final\%20Report.pdf (accessed 02 December 2020).

Ntim, C.G., Opong, K.K., Danbolt, J. \& Thomas, D.A. (2011). Voluntary Corporate Governance Disclosures by Post-Apartheid South African Corporations. Journal of Applied Accounting Research, 13, (2), 122-144.

OECD. (1999). OECD Principles of Corporate Governance, Paris, OECD Publications

OECD. (2004). OECD Principles of Corporate Governance, Paris, OECD Publications.

Okeahalam, C. C. \& Akinboade, A. A. (2003). A Review of Corporate Governance in Africa: Literature, Issues and Challenges. Global Corporate Governance Forum, 1-34.

Okpara, J. O. (2011). Corporate governance in a developing economy: Barriers, issues, and implications for firms. Corporate Governance, 11, 184-199.

Ranti, U. O. (2011). Corporate Governance and Financial Performance of Banks: A Study of Listed Banks in Nigeria, available at: https://www.academia.edu/29350735 (accessed 17 February 2014).

Renders, A., Gaeremynck, A., \& Sercu, P. (2010). Corporate-Governance Ratings and Company Performance: A Cross-European Study. Corporate Governance: An International Review, 18(2), 87- 106 
Roberts, M. R., \& Whited, T. M. (2011). Endogeneity in empirical corporate finance. Available at: http://ssrn.com/abstract=1748604v (accessed 22 September 2019).

Roodman, D. (2009). How to do xtabond2: An introduction to difference and system GMM in Stata. Stata Journal, 9, 86-136.

Rossouw, G. (2005). Business Ethics and Corporate Governance in Africa. Business \& Society, 44(1), 94-106.

Scholtz, H. \& Smit, A. (2015). Factors influencing corporate governance disclosure of companies listed on the Alternative Exchange (AltX) in South Africa. South African Journal of Accounting Research, 29(1), 2950.

Sener İ \& Karaye A. B. (2014). Board Composition and Gender Diversity: Comparison of Turkish and Nigerian listed Companies. Social and Behavioral Sciences, 150, 1002-1011.

Sener İ \& Karaye A. B. (2015). The Effect of Ownership Concentration and Board Committees on Financial Performance: Evidence from Turkish and Nigerian Listed Companies. ICAN journal of Accounting and Finance, 118-135.

Shen, C. \& Chih, C. (2007). Earnings Management and Corporate Governance in Asia's Emerging Markets. Corporate Governance, 15(5), 1000-1021.

Sinclair, A. (1995). The chameleon of accountability: forms and discourses. Accounting, Organization and Society, $20(3), 219-237$.

Tabachnick, B. G. \& Fidell, L. S. (1996). Using Mulitvariate Statistics, New York, Harper \& Row.

Vaughn, M. \& Ryan, L. V. (2006). Corporate Governance in South Africa: a bellwether for the continent. Corporate Governance, 14 (5), 504-512.

Waweru, N.M. \& Uliana, E . (2005). Predictors of management accounting change in South Africa: Evidence from five retail companies. South African Journal of Accounting Research, 19(1), 37-71.

Waweru, N. (2014). Determinants of quality corporate governance in Sub-Saharan Africa: Evidence from Kenya and South Africa. Managerial Auditing Journal, 29(5), 45.

Wei, G. (2007). Ownership Structure, Corporate Governance and Company Performance in China. Asia Pacific Business Review, 13(4), 519-545.

Wei, T. L., Davey, H. \& Coy, D. (2008). A disclosure index to measure the quality of annual reporting by museums in New Zealand and the UK. Journal of Applied Accounting Research, 9(1), 29-51.

Wintoki, M. B., Linck, J. S., \& Netter, J. M. (2012). Endogeneity and the dynamics of internal corporate governance. Journal of Financial Economics, 105, 581-606. 